\title{
Plato: The Virtues of Philosophical Leader
}

\author{
Ioanna-Soultana Kotsori \\ University of Peloponnese, Kalamata \\ Faculty of Humanities and Cultural Studies
}

Received 22 February 2018 - Revised 25 May 2018 - Accepted 11 June 2018

\begin{abstract}
The entrance into the reflection of the present work is made with the philosophical necessity of the leader in society, the leader with the particular characteristics of love and wisdom, from which his personality must possess so that by art he can compose opposing situations and move society towards the unity and bliss of citizens. A gentle royal nature (genotype), which blends with the excellent treatment of morality, body and spirit, will create the ideal model leader (phenotype). Thus, noble nature and royal law will give the state the excellent leader. Even if the forms and the conditions that determine them change, the one that remains stable and permanent is the Platonic ethos in art and the science of politics and administration in general. The salvation from corruption is from childhood the cultivation of man by treating at the same time the moral of the soul, the beauty of the body and the wisdom of the spirit.
\end{abstract}

Keywords: philosophical king, education, wisdom, ethos, leader, excellent state, virtues.

\section{Introduction}

Plato's works demonstrate that he cared for man and society, trying to radically improve morality. Plato's character was not such as to pursue leadership positions to meet his personal needs and shows his responsibility to the leader's heavy role.

Plato's democratic consciousness and the Republic does not allow the separation of the lords and the commoners in the sense of dominating them: on the contrary, he considers the rulers of the social group to call these saviors and Epikouroi, situations and philosophical political positions that will later be clear to the Political in the political ethos of the leader in Plato's Laws.

The psychological character of the leader at Plato was the complex athletic type of man, whose traits are the mixing of power and wisdom with predominant characteristics of his love for society as a sacrifice, creations and reforms, simplicity and democracy, boldness and consistency, research and truth.

They are people who inspire confidence suitable for leading roles, in which the philosophical nature and the royal dynamism mix to make the philosopher king of Republic, the political leader of the Political, and the philosophical democratic ruler of the Laws.

A gentle royal nature (genotype), which blends with the excellent treatment of morality, body and spirit will create the ideal model leader (phenotype). Thus, noble nature and royal law will give the state the excellent leader.

(C) Authors. Terms and conditions of Creative Commons Attribution 4.0 International (CC BY 4.0) apply. Correspondence: Ioanna-Soultana Kotsori, e-mail: ioannakotsori@gmail.com. 
One is the art and science of the administration: we will meet Plato in his writings, be it political or strategic: for this reason, Plato's moral ethos applies to both the politician and the warlord and for the judiciary or any other leader.

Even if the forms and the conditions that determine them change, the one that remains stable and permanent is the platonic ethos in art and the science of politics and administration in general. That is to say, the law is intertwined with the wrong, the strong with the impossible, the temperament with pleasure, the interest with essence, the prowess with the fear, the love with hatred, the intellect with the nonsense, the slave with the despot and generally what is called virtue with evil.

What is the means of salvation from corruption? Plato himself sees from childhood the cultivation of man by treating at the same time the moral of the soul, the beauty of the body and the wisdom of the spirit. And in case that politics and general administration are shaped and evolved through reality, which moves and flows according to the seasons, Plato's leading ethos remains unchanged over the ages.

From the writing time of Plato's works we observe: The charismatic leader, the leader of the divine gift, is shown in Lahis and Menon in the youthful years of Plato. In the Republic and Political, which were written when he was a middle-aged man - the youthful momentum is added to the maturity - the philosopher lordship shows up. On the contrary when the Laws were written, he was in his elderly and elected by the people for a certain time: we notice that Plato was dynamic and auditory in the philosophy of his leadership, stressing with great emphasis the importance of shaping good leadership morality and how this is achieved through the list Education and Culture.

Plato was dynamic and verifiable in the philosophy of his leadership, stressing with great emphasis on the importance of shaping good leadership morality and the way this is shaped through appropriate education and culture.

\section{The excellent State and the philosopher leader}

First of all, the philosopher's kingdom dominates and diffuses in the whole Plato's works inasmuch as it goes hand in hand with Platonic virtue. The way to achieve the state of excellence and to stop the sinful states is: the philosophers will become within the kings of the cities or the so-called kings today and the dynasties will have to philosophize genuinely and competently. To coincide with the same person and political power and philosophy (Bormann, 1973: 63), whereas today it is the opposite that these two natures are forced to go separately and to exclude the coexistence of both. When philosophers become kings, to the extent that this is feasible, the excellent state will appear (473d).

Following the dialogue in the Republic, it is agreed that those characteristics will be given to the philosophers in order to prove themselves worthy enough to take power and to show that some are naturally made to engage in philosophy and become leaders in the city, while others are not made by nature to engage in philosophy and are further intended to follow the leaders philosophers (474b-c).

The Republic seeks to identify the philosophical traits (475a-b). The dominant feature of the philosopher is his love for total wisdom and not part of it $(475 \mathrm{e})$.

Also, the philosopher finds joy in the enjoyment of every lesson and with all his heart drives for learning and again he does not greet $(475 \mathrm{c})$. A thirst for learning related to the pleasure the philosopher finds in view of the truth: he has love for the truth and he hates the lie.

In addition, it is agreed in the Republic that leaders within the city should become the ones who on their faces gather administrative experience and philosophical knowledge. A true philosopher is considered gifted with wisdom and dislike for money (484b-485a). 


\section{Philosopher leader virtues}

As Plato says, all bad things happen in the city, but also every authority and authority when virtue is missing from them (415 d). When man is lacking in virtue, this person is unhappy, because he cannot rule himself and therefore suffer. When such a person happens to have a leading posture, it will drift into the non-government all the society that leads.

In other words, a man who cannot rule himself and has been submitted to pleasures, richness, pricelessness, unbridled freedom, he is not suitable for a leader. The leader must be distinguished from the strong will of the courage of pleasure and the power of virtue.

Acquiring good goods is a virtue to Plato, since the king's philosopher aims at the city's happiness by acquiring goods. For this reason, the goods are divided into two species in divine and human and, moreover, the divine depends on the other (432c, 456b).

The smallest (human) is mainly health, the second is beauty, the third is the physical power and the other moves, and finally the wealth, not blind but sharp, if of course connected with wisdom. Of the divine goods that prevails is the wisdom, the second is wisdom after reason; these, after being mixed up with the prowess, will become the third of the good of justice, and the fourth the bravery.

We will remain especially in the Divine, in the virtues of the soul, and will seek their analysis in the order that Plato himself has defined in the Laws, that is, he first mentions wisdom, secondly wisdom after reason, third the righteousness of justice fourth the bravery.

\subsection{Wisdom}

Wisdom is the first, the crown of all virtues and wisdom is also the mind and the knowledge together with the love and desire that follows (Thornton, 1997: 240). In addition, wishes and desires are done to the contrary if they do not follow wisdom (Laws, 687e-683d). Wisdom is the primary source of the origin of all other virtues, because wisdom means anger, a right decision (i.e., wisdom and justice) in order for the right decision to lead to bravery, which ultimately means a successful attitude or behavior of man to purpose (689c).

\subsection{Prudence}

Immediately after wisdom follows the virtue of wisdom, which, as Plato says in the Republic, looks more to his previous virtues with some agreement and harmony (Sue, 2006: 85). The wisdom is assumed to be a harmonious order and dominion over some pleasures and desires and as the world says using the well-known expression of "being superior to oneself" (430e).

The expression "superior to himself" indicates that there is an upper and a lower part in the soul of man, and that it is natural for the superior to dominate the inferior, and when this occurs the expression "superior to himself" is expressed.

\subsection{Justice}

The other title of Plato's Republic is "On the right", so the main material of the virtue of justice from the Republic will be taken to determine its essence. In the state there is a separation of virtue and evil, and justice is established with virtue and injustice with evil (348b).

The first principle of justice is that everyone should work in an area which is by nature intended and the second principle is friendship between members of society either as a virtue or 
as written or unwritten laws in order to maintain the social balance. Injustice generates atrocities and hatred and altercation, but fairness, unity and friendship. Therefore, the just soul and the righteous man will live well, the unjust one bad (351d).

It is undeniable that the implementation of justice in leadership brings sweet and rich fruits (Vlastos, 1973: 299) as it creates feelings of security and prowess to working citizens when they know they will find their law by power, with the result that all citizens really aim for the prosperity of their city (356d).

Injustice as perfect as it may and may be hidden and detached instead of the word of praise, glories, honors and gifts will in the end be discovered because it has nothing to do with the truth, which always shines in the light, if temporarily justice is mistaken.

\subsection{Prowess}

If justice with wisdom and wisdom acts for the balance in nature and in the society of men, the virtue of bravery creates and ensures the conditions of their evolution. The value of the virtue of bravery for the leader is clearly seen in a state of the Republic: leaders are those who are very prolific, others who are less prolific follow (564b).

Speaking then, Plato for political prowess in the Republic would say that a city is called cowardice or bravery, observing and studying the class of citizens who are making wars and campaigns to defend it (Devereux, 2008: 106). Bravery is characterized as enduring fears and sorrows or desires and pleasures and some terrible flattery reasons that make hearts soften as wax, even those that are considered rigorous (633d).

Plato suggests acquaintance from young age, fear and sadness and pleasure, so that the person does not fall into even more unpleasant situations of dependence and slavery, but familiarity with all this to maintain his self-sufficiency and self-reliance. Citizenship must be such that the individual can control himself and his pains and pleasures in full consciousness. That end which will manage to take first of its own selves, will have taught the others. This victory against the weaknesses of ourselves is virtue and declares an act of bravery (388d).

\subsection{Relation of virtues}

Taking into account the hierarchy and the characterization of these qualities by Plato in the Laws, namely wisdom first, wisdom with logic, third the righteousness, and fourth the bravery, may lead to the conclusion that Plato considers fundamental virtues wisdom and prowess, a derivative of these wisdom and righteousness (Georgiadis, 1991: 146).

The hierarchy of the virtues of Plato's Laws is not a matter of priority for the substantive evaluation of these but relates to the order of appearances and the application of virtues.

Thus, one end is the wisdom, namely the right opinion and decision, at the other end is bravery as an act and application for progress, evolution and creation. While the virtues of wisdom and righteousness, related to harmony, measure and balance are in the middle and are a synthesis of the two extreme virtues (Penner, 1973: 56, 57).

What kind of leadership principles would Plato want to teach, so that the leader's decisions are beneficial to the society he manages and cares for? 


\subsection{The principle of dialectics}

This principle must define the true essence of things, not the one that does not exist. With these thoughts, Plato defining dialectics (Political, 285c-287a) also defines his goals, which cannot be but the separation of things and the discovery of their essence, the discovery of the truth that exists within them (Gill, 2004: 286). That is why Plato, without abandoning the method of comparisons of the sizes and the relations of things to each other in order to find the right in an easy and quick process, strongly recommends as the first purpose the thorough dialogue and preferably the divisive method to find the truth or to make the right decision of the leader.

Plato uses dialectics only to reveal the truth, which transcends human experience, but uses it also for decisions of practical significance, so the Platonic dialogues of the interlocutors set out all the possible aspects of a subject in order to enlighten all the truth and make good decisions about a subject.

Plato's dialectics is an evolutionary continuation of the "obstetric" method of the Socrates teacher, but at the same time it is purely proof of Plato's open democratic consciousness, regardless of the political philosophical positions he expressed in the course of his life for the sake of a harmonious state (Guthrie, 1971: 221, 222, 225, 226). Also, this deep democratic consciousness reveals Plato when he considers and recommends dialectics as the most appropriate method and in education, obviously as a better tool for the cultivation of intellect, for the mental satisfaction of the pupils in the production of knowledge but at the same time for the cultivation of the democratic consciousness of students.

\subsection{The beginning of the measure}

As a consequence of the dialectic principle and art, we can say that it is the measure so that the decisions of the leader ensure and maintain harmony and unity in unequal and opposing situations (Laws, 690e, 693c, 875b) within the city or any other social group they manage, so as not to destroy the whole society from these situations.

So, for the good and good works, which are the essence of the measure, it is imperative that the exaggeration and the lack, the larger and the smaller and all the similar sizes, become symmetrical, not only among themselves, but also with regard to the measure which expresses their own regularity. This is a very difficult and laborious task, Plato says, but it is necessary and just to set this principle of measure to show what accuracy is (Political, 283a, 283b-284c, 284c$285 \mathrm{c}$ ). This unique technique for finding the measure, Plato sets in on meter which can apply to all sciences and the arts.

\subsection{The principle of unity}

This harmony in society is achieved by cultivating unity among the peoples on the part of the leaders. Thus, apart from the beginning, unity also emerges as one of the main purposes of leadership, for whose success Plato again recommends the same, as for the other principles of leadership, the art of warp and weft (Political, 309d, 309e, 310a), through which weaving the cloth into a single creation, however different the cloth components are.

Plato, of course, considers the basic factor in the unity of citizens to be properly treated, but the quality of the friendly bonds that develop among people is not neglected, noting that the friendly ties between the bad guys among themselves and between the bad and the goods are not stable. So, those bad citizens are also doubtful about the effects of proper education, and the need for law enforcement to emerge, fearing these consequences to maintain social peace, as is evident from Plato's case law. While, on the other hand, good characters, in whom courtesy is 
inherent and supplemented by appropriate treatment, need not oversee the laws, and friendly bonds remain firm among these people.

Great is the significance which the philosophers attribute to the value of unity in the city, so that Plato finally wonders: What, in any case, can we characterize as the greatest asset in terms of the organization and goals of a city, and what is the maximum evil? So we know that there is no greater for the city and society of evil than the one that breaks it and one that makes it a lot of pieces or a greater good than the one that binds it together and makes it one?

5. Charisma and science of leadership - Is leader generated or becoming on the way?

The question of whether the leader is born or becomes a concern also in modern times, but in the same spirit we will endeavor to enrich our thoughts with Plato's present, who follow an evolutionary course, obviously according to his age, but also with the circumstances of each time period. Thus, in his early works, such as the one referred to in Menon, he argues that the virtues and the science of leadership are not taught, as there are no suitable teachers to teach them. But also because it considers the right opinion to be equal with science when everyone processes their own work in an effective way, obviously wanting Plato to emphasize that the leader is the primary qualification for his right decisions is the orthognosis and secondarily comes science to addressing the diverse issues of its leadership.

Also, in his views on the teaching or not of the leading science, Plato evolves in his most mature work, the Republic, proposes the philosopher-lord of the city, to whom not only the noble nature and the divine leadership but in addition, those who are destined for leadership roles in the city should receive the best treatment in the soul, body and spirit, as it is determined by him in his Republic.

Plato will speak with the same spirit, as we have seen in the Political, a work of excellence dedicated to science and the art of leadership, and in which he again emphasizes the value of obtaining this science from persons who by their very nature have aunt a donation of the "royal genus", that is, the charisma to be leaders and which is a gift to people regardless of whether they are rulers or ordinary citizens. For this "royal" art, that is, the first and chief among all other arts, neither the multitude of the rich nor all the citizens will ever be able to receive and enjoy as political science, since it is "royal" art and belongs only to the chosen people of the "royal genus", to which it fits.

It is essential, however, that each lord possesses this science and the art of leadership, so that in his administration he is self-sufficient and not dependent on the advice of others on matters of his administration.

\section{Conclusions}

The entrance into the reflection of the present work is made with the philosophical necessity of the leader in society, the leader with the particular characteristics of love and wisdom, from which his personality must possess so that by art he can compose opposing situations and move society towards the unity and bliss of citizens.

In order to stop anarchy, corruption and misery in the city, Plato suggests, with the will of the citizens, that the city's government be entrusted to a philosophical king, who, having certain legislative initiatives, will take root out of the corrupt, rebuild the lawful state of excellence.

Also, in the words of Plato, the aims of the philosopher king are exported and these are: (a) the constant concern for the welfare of the citizens; (b) the cultivation of respect for the divine, while the disrespect for God leads to self; (c) to create good and good citizens to be virtuous, 
prudent and just with unity and friendship with each other; (d) to live and create citizens free but "in justice" within society as a whole; and (e) to make the city self-sufficient in strength and wealth.

Essential to the quality of the leader, Plato considers the proper education, which he sees as a global form of higher courses and exercises, aimed at cultivating the spirit and in the treatment of soul and body.

The most important concern of the Platonic State is that the lords are the few elected by nature and education, who will be wiser and more competent than other citizens to carry out their difficult task, which will be the state's prosperity.

With the desire to rule the excellent, that is, philosophers, Plato is radically dealt with by the political problem, since philosophers are people of exceptional nature, with proven moral endurance, spiritual strength and comprehensive philosophical formation and practical experience. Culture and education, in Plato's view, create the bravery, which is the assessment of bad and risk, so as to achieve the salvation of the city.

\section{Acknowledgements}

This research did not receive any specific grant from funding agencies in the public commercial, or not-for-profit sectors.

The author declares no competing interests.

\section{References}

Bormann, K. (1973). Platon [Plato]. Freiburg im Breisgau: Alber.

Devereux, D. (2008). Socratic ethics and moral psychology. Oxford Handbooks Online.

Georgiadis, G. (1991). Socratic Eros and philosophical activity. In: K. Bourdouris (Ed.), The philosophy of Socrates. Athens: International Center for Greek Philosophy and Culture.

Gill, C. (2004). Afterword: Dialectic and the dialogue form in late Plato. In: C. Gill \& M. M. McCabe (Eds.), Form and argument in late Plato. Oxford: University Press.

Guthrie, W. K. C. (1971). A history of Greek philosophy, Volume III: The Fifth-Century Enlightenment Part 1. The Sophists. Cambridge University Press.

Penner, T. (1973). The unity of virtue. Philosophical Review, 82, 35-68.

Sue, Y.-S. (2006). Selbsterkenntnis im Charmides [Self-knowledge in Charmides]. Königshausen \& Neumann.

Thornton, B. S. (1997). Eros: The myth of ancient Greek sexuality. Boulder: Westview.

Vlastos, G. (1973). Platonic studies. Princeton University Press. 
I.-S. Kotsori - Plato: The Virtues of Philosophical Leader

C O A S 